\title{
Indian Economy Amid COVID-19 Lockdown: A Perspective
}

\author{
Amit Joshi ${ }^{1}\left(\mathbb{D}\right.$, Preeti Bhaskar $^{1,2}(\mathbb{D})$ and Puneet Kumar Gupta ${ }^{1 *}$ (i)
}

${ }^{1}$ ICFAI Business School, The ICFAI University, Dehradun - 248 197, India.

${ }^{2}$ Ibra College of Technology, Oman.

\begin{abstract}
COVID-19 virus has resulted in the lockdown of schools, offices, factories, temples, railway stations, and even the airspace. It is estimated that due to the lockdown, the Indian economy may face prolonged adverse impact. The paper is an attempt to ascertain the impact of lockdown on the Indian economy and explore future perspective. The study has addressed important issues like consumption expenditure, demand \& supply, unemployment rate, purchasing power, financial market, etc. Under the given circumstances, the lockdown will cost India around USD 120 bn. The manufacturing and service sector has come to an abrupt stop and interrupted domestic supply chains. If this crisis continuous it will indirectly affect all economic sectors. The study has given suggestions as a learning curve which can be used by different stakeholder to improve the economic situation of the country and minimize negative effect of lockdown.
\end{abstract}

Keywords: COVID-19, Coronavirus, Lockdown, Crisis, WHO, Economy

*Correspondence: puneetstat999@gmail.com

(Received: April 16, 2020; accepted: May 07, 2020)

Citation: Joshi A, Bhaskar P, Gupta PK. Indian Economy amid COVID-19 Lockdown: A Perspective. J Pure Appl Microbiol. 2020;14(suppl 1):957-961. doi: 10.22207/JPAM.14.SPL1.33

C The Author(s) 2020. Open Access. This article is distributed under the terms of the Creative Commons Attribution 4.0 International License which permits unrestricted use, sharing, distribution, and reproduction in any medium, provided you give appropriate credit to the original author(s) and the source, provide a link to the Creative Commons license, and indicate if changes were made. 


\section{INTRODUCTION}

Human coronaviruses were first identified during 1960 and were responsible for damaging upper respiratory tract infection ${ }^{1}$. Since 2003, at least 5 new human coronaviruses have been identified, including the severe acute respiratory syndrome coronavirus [SARS], which resulted in significant morbidity and mortality in China. It seems that the coronaviruses infecting humans and causing respiratory disease is heterogeneous and quite widely distributed. During December 2019 similar coronavirus COVID-19 was identified in Wuhan, China. Though nothing specific is known as from where it has originated but it is highly contagious as virus generated through respiratory droplets through coughing and sneezing ${ }^{2}$.

The epidemics of COVID-19 have been recorded over 200 countries, territories \& areas along with China and pinched more than 26654 humans, affecting severely around 575,444 cases $^{2}$. On March 11, 2020, World Health Organization changed the status of COVID-19 emergency within 42 days from Public Health International Emergency (January 30, 2020) to a pandemic

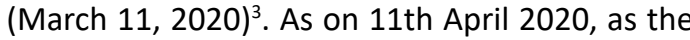
situation of the world still looks grim, numbers of COVID-19 cases are more than 1,614,405 and the worldwide death toll is more than $96789^{4}$.

In India, the first case of COVID-19 was reported on 30th January 2020, originating from a student who traveled from Wuhan, China although successfully recovered from the infection on 14 February $2020^{5,6,7}$. As of $11^{\text {th }}$ April 2020, The Ministry of Health And Family Welfare has confirmed a total of 6565 active cases, 642 recoveries, 1 migration and 239 deaths in the country from 31 State/UT including 66 foreign cases $^{5}$.

On $24^{\text {th }}$ March 2020, prime minister of India announced 21 days complete lockdown for 1.3 billion Indians immediately from midnight, it means no one could leave their home for 21 days, but it seems to be the tip of the iceberg as a notion is that the war with the unseen virus may result in an extended shutdown. The lockdown includes schools, offices, factories, parks, temples, railway stations, and even the airspace. In a recent column for the Hindu, Jean Dreze, a prominent BelgianIndian economist said "almost everybody in India's informal economy-a huge share of the country's work force-has been hit by an economic tsunami's. Economic impact of lockdown due to COVID-19

It is estimated by ICRA rating agency that amid COVID-19 crisis the Indian economy may grow at just $2 \%$ in the current fiscal. The lockdown will have an adverse country where people are much more at risk from the serious consequences of poverty if they go several weeks without working. An predicament protocol has been promulgated in India that avert people from leaving the place they are, however essential supplies, grocery stores, pharmacies, and banks continue to serve for certain hours as deliberated by the Government Public transport have been completely suspended till further orders.

Due to the lockdown, the manufacturing sector of non-essential items in India is shut, resulting in the reduction of workforce and no possibility to hire new employee, which means that disposable income in the economy will fall, ensue fall in aggregate demand and as the deflationary gap between aggregate demand and aggregate supply upsurge there are cogent chances that the Indian economy may be pushed to a situation of recession. As per the Asia Development Bank, on 20.03.2020, the COVID-19 outbreak could cost the Indian economy between $\$ 387$ million and $\$ 29.9$ billion in personal consumption losses ${ }^{7}$. The number of afflicted sufferer in the USA, Italy, and Spain has already surpassed China and India's postulated sequences is becoming perilous and will have an adverse catastrophic impact on the Indian economy.

As the lockdown will continue, the Indian economy will experience a large but temporary decline in consumption growth of $2 \mathrm{pp}$ (percentage points), due to precautionary behaviors and policies adopted by various authorities. It is estimated that with travel bans and precautionary behavior abating after three months, India's hit will be $\$ 640$ million but if the situation worsens and there is prolonged lockdown consumption expenditure in India may decline by $\$ 1.2$ billion. A report issued by the UN Conference on Trade and Development estimated that India could lose \$348 million and declared it among the top 15 most-affected economies, after the EU, the US, Japan, and South Korea. 
COVID-19 and the lockdown that followed may have an adverse influence on the Indian economy in two ways, one externally, it includes: weaker global demand, supply chain disruptions, Lower commodity price, and Risk-off and Global financial shocks. Second internally that is through the domestic channels, which include: Reduced discretionary spending, factory shutdowns, and travel restrictions. It is evident that there will be a cuneate array of concurrently functioning jolt resulting from the COVID-19 pandemic. The first apprehension is related to supply-side shock resulting from shutdown and suspension of international trade in China, secondly India may experience a fiscal shock as the pandemic has been declared as public health emergency and third shock will arise from oil price as due to fall in global demand we may witness fall in their prices. The financial markets in India are highly volatile, and are reacting to these shocks in perpetuity and the situation will remain the same for an uncertain period. Considering these shocks, the lockdown will cost India around USD 120 bn.

The manufacturing and services sector have come to an abrupt stop and interrupt domestic supply chains. As the revenue of the companies reduces, the contractual laborers and daily wage earners will be in the line of fire. The impact of all this will vary by sector, but services would be hit particularly hard and there is a risk of long-term loss of demand and capacity in both industrial and services sectors if the crisis prolongs. Credit Rating Information Services of India Limited on February 20, 2020, stated that India that economy of India will be in great danger if the pandemic continues for a long period. As the household sector has been asked to remain indoors, the aggregate expenditure will fall, giving a jolt to circular flow of income in the economy. With flights grounded, Visas cancelled, Transportation suspended, empty hotels, malls, multiplexes and restaurants closed the businesses in India is at all-time low.

Due to uncertainties, doubts and less clarity about the cause of pandemic, demand for poultry products has considerably reduced. Physical restrictions have caused the service sector to be adversely affected. Fall in business volumes and suboptimal utilization of resources will result in losses to companies. All this may lead to damage the credit portray.

GDP growth during the next fiscal is expected to plunge to $3.5 \%$ in pandemic aftermath the pandemic in India and the consequent lockdown for 21 days pose a material risk to the economic outlook of India. The adverse effects that will follow can dwarf the gains from the sharp drop in crude oil prices, and the anticipated monetary and fiscal stimuli. The unemployment rate according to Centre for Monitoring Indian economy projects a spike in the unemployment rate in the first week of April 2020 to 23.8\%, the labor participation rate fell to $39 \%$ and the employment rate was $30 \%{ }^{8}$.

The lockdown to curtail COVID-19 has stalled workers under the rural jobs guarantee scheme, leaving daily wage workers with little to fall back on. As major businesses are put on hold, it has mainly hurt daily wage earners, contractual laborers, and self-employed workers in the informal economy in rural and urban areas, pushing them out of jobs amid the nation's high unemployment rate. MGNREGA employs 266 million workers, of which 128.1 million are active, according to the website, in the ongoing financial year 77.5 million holds individuals from 54 million households have been employed under the scheme ${ }^{9}$. The rising unemployment rate means less distribution of income and less purchasing power which would lead to negative savings and fall in the consumption expenditure. The deficient demand thus arising may create a situation of recession with a long term impact on the Indian economy.

Considering the catastrophic impact of the lockdown on the Indian economy, it may be argued that the government should have been relaxing as far as the complete lockdown of the economic activity. However, if we assess the Swedish model, unlike India, they did not impose restrictions rather they advised people for selfdiscipline. State epidemiologist Anders Tegnell at the National Institute of Public Health advised the citizens of Sweden to continue the economic activities until and unless they are visibly sick, irrespective of the fact that their family members were infected. As on May 4, 2020 there are 22721 people infected in Sweden out of the total 
population of 10.3 million as compared to India where out of the total population of 1380 million 42836 are infected in Sweden, 2769 people have lost their lives due to pandemic whereas 1389 people lost lives in India ${ }^{10,11}$. In both situations India's decision of lockdown is justified, perhaps it believes in saving lives will save the economy.

Future Perspective

The COVID-19 has created a grave situation and what is petrifying is that we are not sure when the situation will normalize, until then India has to fight a lonely battle. India has little policy firepower to give a consequential shove to progress, and the pandemic has created more stringent barriers. The biggest challenge in front of India is to finance the government deficit, which is rising due to increased expenditure and reduced revenue. Though there is marginal support due to fall in the global oil prices, it will take a long time to reduce the deficit. One may expect rationalization of all direct taxes and corporate taxes, in order to augment businesses. There will be a precipitous deceleration in global growth and India's trade, what is unforeseeable is the magnitude of the impact on the economy through domestic channels of production (supply) and consumption (demand). With the number of COVID-19 cases continuously increasing, the impact of the virus on global sentiment, economic and otherwise, has been immense.

COVID-19 has created a barricade for the Indian Human Resource anticipate with great apprehensions job dismissal and salary cuts are expected in the vulnerable service sectors, which include airlines, tourisms, malls, multiplexes, restaurants, retailers, film industry, Pharmaceuticals, etc. As companies are not able to generate revenue the employers may reduce their cost by reducing their workforce. The cash flow in the economy is curtailed due to less economic activity resulting in an adverse impact on all payments including to those for employees, interest, loan repayments, and taxes, thus making the Indian economy vulnerable.

\section{Learning Curve}

Every difficulty gives an opportunity to learn, COVID-19 is no different. With a reduction in pollution, less petrol consumption and no road accidents, this dark cloud also has a silver lining. There is no guarantee that such types of situations will not occur in the future, provided there should be learning. One such learning is for the companies is to equip themselves with remote working, many companies have faced this situation that their employees are not well versed with the technology advancement due to lack of training and many companies do not have the feasibility to promote work from home.

People have realized the importance of technology in business. Various platforms are being used by employers to train their employees. It is turning out a win-win situation for employers and employees. Employees are getting flexible timings, they are able to maintain work-life balance and able to save more as they do not spend on commute.

Employers, on the other hand, are benefitting as the cost of the establishment has reduced, better work-life balance of the employees has increased their productivity ${ }^{12}$. Working from home could be the new normal for many employees as more major employers and CEOs, including Mondelez, Nationwide and Barclays, talk about a permanent shift to work from home and reduced office space ${ }^{13}$. "HR heads of Axis Bank, Bank of Baroda, RPG Group, Vedanta, EY, Cognizant, Titan, Deloitte, Whirlpool, Paytm, SaintGobain India, viewed virtual workplaces are the future of work.".

Lockdown has left organizations with no plan for contingencies and continuity. Proper hygiene and safety for employees is a musty organization irrespective of the situation, if proper care is taken then the companies can continue their work, proper screening of the employees sterilization of office establishment, setting up of medical and counseling team and distribution of safety kits to the employees could be some initiatives that companies could have followed to prevent a complete lockout.

COVID-19 has created a big roar due to barrier in communication, proper and clear instructions to the employee is missing, like the government has asked the schools not to accept the fee for three months but if schools will not accept the fee how they will pay the staff. Those organizations that are having an open line of communication with their stakeholders are able to face the challenges. 
According to the System of Air Quality and Weather Forecasting and Research (SAFAR) one positive impact of the lockdown is remarkable control of air pollution, with no vehicles immersing dangerous gases, no fires in blasting furnace, level of nitrogen oxide in the atmosphere since March 5,2020 have fallen by around $45 \%$ in Mumbai and Pune, and by $50 \%$ in Ahmedabad, as compared to the levels recorded in 2018 and $2019^{14}$.

India may shift the line of production temporarily in a phased manner to those places where the epidemic is controlled and capture potentially $40 \%$ of their competitor's market by enhancing the make in India concept ${ }^{15}$. Although the Wuhan coronavirus outbreak could have a significant impact on the Indian pharmaceutical industry unless it is brought under control over the next few months, it also provides an opportunity for India's pharmaceutical manufacturers to grab share from their Chinese competitors ${ }^{16}$.

\section{ACKNOWLEDGMENTS}

None.

\section{CONFLICT OF INTEREST}

The listed author(s) declare no conflict of interest in any capacity, including competing or financial.

\section{AUTHORS' CONTRIBUTION}

All listed author(s) have made a substantial, direct and intellectual contribution to the work, and approved it for publication.

\section{FUNDING}

None.

\section{ETHICS STATEMENT}

This article does not contain any studies with human participants or animals performed by any of the authors.

\section{AVAILABILITY OF DATA \\ Not applicable.}

\section{REFERENCES}

1. Centre for Disease Control and Prevention. Human Coronavirus Types. 2020. [Online] Available from: https://www.cdc.gov/coronavirus/types.html

2. Kahn JS, Mclntosh K. History and recent advances in coronavirus discovery. Pediatr Infect Dis J. 2005;24(11):S223-7. https://doi.org/10.1097/01. inf.0000188166.17324.60

3. https://www.worldometers.info/coronavirus/?

4. https://www.who.int/emergencies/diseases/novelcoronavirus-2019

5. https://www.mygov.in/covid-19/

6. https://www.thehindu.com/opinion/lead/the-perilsof-an-all-out lockdown/article31136890.ece

7. Abiad A, Arao RM, Dagli S. The Economic Impact of the COVID-19 Outbreak on Developing Asia. 2020. https:// doi.org/10.22617/BRF200096

8. https://www.businesstoday.in/current/economypolitics/coronavirus-fallout-unemployment-ratespikes-to-23-after-lockdown-says-cmie/story/400349. html

9. https://nrega.nic.in/

10. World Health Organization. Coronavirus(Covid-19). 2020. Available from https://covid19.who.int/ accessed on May 05, 2020.

11. https://www.statista.com/

12. https://economictimes.indiatimes.com/jobs/workfrom-home-going-to-stay-even-after-covid-scare-isover/articleshow/74956231.cms?from $=\mathrm{mdr}$

13. https://www.cnbc.com/2020/05/01/majorcompanies-talking-about-permanent-work-fromhome-positions.html

14. http://safar.tropmet.res.in/

15. https://bfsi.eletsonline.com/covid-19-and-its-impacton-indian-economy/

16. https://economictimes.indiatimes.com/news/ economy/foreign-trade/ 